\title{
Number and function of Sertoli cells, number and yield of spermatogonia, and daily sperm production in three breeds of boar
}

\author{
O. E. Okwun ${ }^{1,2}$, G. Igboeli ${ }^{3}$, J. J. Ford ${ }^{4}$, D. D. Lunstra ${ }^{4}$ and \\ L. Johnson ${ }^{1 *}$ \\ ${ }^{1}$ Department of Veterinary Anatomy and Public Health, College of Veterinary Medicine, Texas A\&M \\ University, College Station, TX 77843, USA; ${ }^{2}$ Department of Animal Production, University of \\ Agriculture, Makurdi, Nigeria; ${ }^{3}$ Department of Animal Science, University of Nigeria, Nsukka, Nigeria; \\ and ${ }^{4}$ USDA ARS, Reproduction Research Unit, RLH US Meat Animal Research Center, Clay Center,
}

NE 68933, USA

\begin{abstract}
The objective of this study was to determine the number of Sertoli cells per boar, daily sperm production, and germ cell yield per type A spermatogonium in mature Whitecross, Meishan, and West African boars. The paired parenchymal mass was greatest in the Whitecross boars and greater in Meishan than in West African boars. Daily sperm production per boar $\left(\times 10^{9}\right)$ differed significantly $(P<0.05)$ among breeds (Whitecross: $12.5 \pm 1.5$; Meishan: $6.0 \pm 0.5$; West African: $2.9 \pm 0.3$ ). Daily sperm production per boar was positively $(P<0.01)$ correlated with parenchymal mass $(r=0.97)$, number of A spermatogonia per testis $(r=0.88)$, and Sertoli cells per testis $(r=0.87)$. Daily sperm production per gram of testis was similar among breeds. Number of Sertoli cells and number of type A spermatogonia per boar were greater for the Whitecross but similar in the Meishan and West African boars. The number of Stage VII germ cells per Sertoli cell was greater $(P<0.05)$ in the Meishan $(39.08 \pm 5.07)$, but similar in the Whitecross $(19.91 \pm 1.62)$ and West African boars ( $15.81 \pm 2.43)$. The number of type A spermatogonia per testis was highly and positively $(P<0.01)$ correlated with number of Sertoli cells per testis $(r=0.95)$, and parenchymal mass $(r=0.88)$. There was a trend for the spermatid yield per type $A$ spermatogonium to be greater in the Meishan boars, and this ratio was positively correlated with spermatid:Sertoli cell ratio $(r=0.62)$ but not with daily sperm production per boar or Sertoli cells per testis. No significant germ cell degeneration occurred during the long meiotic prophase, but the loss of progeny during postprophase of meiosis averaged $32.62 \%$ across all breeds. Germ cell degeneration was similar $(P>0.05)$ across breeds during spermiogenesis, and on average amounted to $8.6 \%$. The increased number of type $A$ spermatogonia and of Sertoli cells associated with larger testes for the Whitecross over West African or Meishan boars is sufficient to explain the higher sperm production in the Whitecross. However, the lower index of degeneration and more efficient Sertoli cell function in Meishan boars results in the daily sperm production being intermediate between that of the Whitecross and West African boars.
\end{abstract}

\section{Introduction}

The Chinese Meishan breed of pig reaches puberty earlier and has higher prolificacy, ovulation rate, and litter size than do common US and European breeds of pig (Haley et al., 1990; Harayama et al., 1991; Borg et al., 1993). The testes of Meishan males produce motile spermatozoa as early as 75 days of age (Harayama et al., 1991; Lunstra et al., 1992), and comparative studies of common US breeds versus the Meishan breed allow the investigation of factors influencing onset of puberty and increased prolificacy.

*Correspondence.

Received 30 October 1995
The indigenous West African boar, though largely unimproved, shows a certain degree of tolerance or resistance to trypanosomiasis (Birkett, 1958). As a result, it is readily used in swine improvement programmes aimed at upgrading the local stock and stabilizing the more vulnerable exotic genotypes within the West African tropical zone. However, marked differences in semen quality, including the number of spermatozoa in ejaculates, between this breed and other exotic breeds (Swierstra, 1973; Akinkpelumi, 1981; Borg et al., 1993) have not been explained. Furthermore, we are unaware of any study that has directly compared ejaculate characteristics among different breeds of boar. Hence, the physiological mechanism by which breed contributes to this variation in seminal quality 
has not been investigated. Differences in testicular size and composition, quantitative relationships among germ cells at different developmental steps and Sertoli cells, variations in daily sperm production, and germ cell degeneration during normal spermatogenesis may well relate to the number of spermatozoa in the ejaculate. Thus, comparison of daily sperm production and spermatogenic efficiency in testes of boars from breeds of three markedly divergent origins may provide new models and insights for studying mechanisms controlling boar reproductive capacity.

A comparison of body or testicular mass in the Whitecross, Meishan, and West African breeds reveals a rigid pattern of variance. Given that sperm production among them may follow a similar pattern, the objectives of the present study were (1) to determine daily sperm production in the Whitecross, Meishan, and West African breeds, (2) to quantify the amount of germ cell degeneration at various steps of normal spermatogenesis, (3) to determine whether differences in the rate of germ cell degeneration contribute to breed differences in daily sperm production, and (4) to examine the number of Sertoli cells and testicular characteristics that may explain breed differences in daily sperm production.

\section{Materials and Methods}

\section{Specimen and histologic preparation}

Testes from five mature ( 332 days old) West African boars (raised in Nigeria) were weighed after the fascia and epididymis had been removed. Parenchymal mass was determined by subtracting the mass of the tunica albuginea from the total testicular mass. Parenchymal volume was determined by dividing the parenchymal mass by the average specific gravity of parenchyma obtained by dividing the mass of a piece of tissue when immersed in water by the mass when suspended in water. Slices of tissues $\left(1-1.5 \mathrm{~cm}^{3}\right)$ from different regions within the testis were placed in freshly prepared Zenker-formol fixative for $24 \mathrm{~h}$, washed in running water for $24 \mathrm{~h}$, and stored in $70 \%$ alcohol until processed (Humason, 1967). Similarly, testes from five mature Whitecross (346 days old) and Meishan (225 days old) boars (raised in Nebraska) were weighed and perfused with glutaraldehyde in cacodylate buffer, freed from fascia and the parenchymal mass and volume obtained as described for the West African. Slices from different regions of the testes were fixed in $2 \%(\mathrm{v} / \mathrm{v})$ glutaraldehyde in $100 \mathrm{mmol}$ cacodylate buffer $\mathrm{I}^{-1}$ and subsequently stored at $5^{\circ} \mathrm{C}$. Smaller slices $(5 \mathrm{~mm} \times 10 \mathrm{~mm} \times 10 \mathrm{~mm}$ ) of the glutaraldehyde-fixed parenchyma or Zenker-formol-fixed tissue were further fixed in $1 \%$ $(\mathrm{w} / \mathrm{v})$ osmium in cacodylate buffer, dehydrated in alcohol, and embedded in Epon 812. Sections cut at $0.5 \mu \mathrm{m}$ were stained with toluidine blue and observed with brightfield microscopy, while those cut at 10 or $20 \mu \mathrm{m}$ were observed unstained by Nomarski optics. All evaluations were carried out in one location (Texas) and by one technician.

\section{Classification of the stages of the cycle of the seminiferous epithelium}

The identification of the stages of the seminiferous epithelium was based on the observation of germ cell nuclear chromatin and cytoplasmic details in the $0.5 \mu \mathrm{m}$ histologic sections by brightfield microscopy. On the basis of nuclear morphology of spermatids, as well as the relative position of the more mature spermatids within the seminiferous epithelium in relation to the luminal surface (Curtis, 1918; Roosen-Runge and Giesel, 1950), the eight-stage classification was used (Swierstra, 1968a; Ortavant et al., 1977). Since the morphology of germ cells and architecture of the seminiferous tubules were similar in the three breeds, photomicrographs that illustrated the details of each stage were picked randomly from across the breeds.

Determination of the relative duration of the stages of the cycle of seminiferous epithelium

One hundred tubular cross-sections per animal were scored on $0.5 \mu \mathrm{m}$ Epon sections to determine the frequency of stages. Although occasionally tubular cross-sections displayed multiple stages, only those with singular cellular associations were counted.

In randomly selected sections of seminiferous tubules from a large sample size, stages of long duration tend to appear more frequently than those of shorter duration (Clermont and Trott, 1969). Thus, the relative duration of the various stages of the seminiferous epithelial cycle were assumed to correspond to the relative frequencies with which they occurred in crosssections of tubules analysed. Relative frequencies of stages were not different among breeds and therefore were pooled, and the average used in deriving the relative durations of the stages based on 8.6 day cycle length for the boar (Swierstra, 1968a). It is assumed that cycle lengths are similar for the three breeds (Berndtson, 1977). However, it should be noted that due to the small sample size evaluated in this study, the possibility of detecting breed differences in stage frequencies is limited.

\section{Stereologic evaluation of tissues}

The $0.5 \mu \mathrm{m}$ Epon sections under brightfield microscopy at $\times 1000$ magnification were used to determine the volume densities or percentage of parenchyma occupied by nuclei of germ cells and Sertoli cells by means of a 50-point ocular grid using the point-counting method of Chalkley (1943). A total of 10000 hits made on each boar was sufficient to achieve a high precision, with an average coefficient of variation for repeated measurements on the same boar of 8,11 and 15, respectively, for pachytene spermatocytes, spermatids with spherical nuclei, and Sertoli cell nuclei. Randomness and sufficient sampling were achieved by the use of three or four sections on a slide and by uniform movements of sections in both axes during examination under a microscope. Nuclei of germ cells counted included type A spermatogonia (stages I-VIII), type B spermatogonia (stages VI-VIII), leptotene primary spermatocytes (stage I), pachytene primary spermatocytes (stages V-VIII and I-III) and spermatids with spherical nuclei (stages V-VIII and I). The volume density of each component (above) multiplied by total parenchymal volume (parenchymal mass) $\left(1.05 \mathrm{~g}^{-1} \mathrm{ml}^{-1}\right.$ ) yielded the total volume of that component per boar or paired testes. 
Table 1. Relative frequencies and duration of the eight stages of the cycle of the seminiferous epithelium in three breeds of boar

\begin{tabular}{rrrrrr}
\hline Stage & \multicolumn{2}{c}{ Percentage frequency } & $\begin{array}{c}\text { Duration } \\
\text { (days) }\end{array}$ \\
\cline { 2 - 5 } & Whitecross & Meishan & West African & Average & \\
\hline I & $16.20 \pm 0.97^{\mathrm{a}}$ & $11.40 \pm 0.93^{\mathrm{b}}$ & $13.50 \pm 0.97^{\mathrm{ab}}$ & $\mathbf{1 3 . 6 4 \pm 0 . 6 9}$ & 1.18 \\
II & $11.80 \pm 1.65$ & $10.20 \pm 0.73$ & $12.25 \pm 1.84$ & $11.68 \pm 1.07$ & 1.01 \\
III & $7.40 \pm 1.08$ & $6.40 \pm 0.74$ & $6.58 \pm 1.07$ & $6.73 \pm 0.64$ & 0.58 \\
IV & $11.80 \pm 3.10$ & $12.20 \pm 1.74$ & $10.58 \pm 1.37$ & $11.23 \pm 1.05$ & 0.99 \\
V & $7.20 \pm 1.56$ & $9.00 \pm 0.89$ & $8.17 \pm 1.45$ & $8.13 \pm 0.87$ & 0.70 \\
VI & $15.40 \pm 1.43$ & $18.60 \pm 0.68$ & $17.17 \pm 1.66$ & $17.09 \pm 0.98$ & 1.48 \\
VII & $15.80 \pm 2.48$ & $16.40 \pm 1.08$ & $16.83 \pm 1.51$ & $16.50 \pm 0.99$ & 1.41 \\
VIII & $14.40 \pm 1.78$ & $15.80 \pm 0.80$ & $14.92 \pm 1.58$ & $15.00 \pm 0.94$ & 1.27 \\
\hline
\end{tabular}

Values are means \pm SEM.

a.b Means within rows with different superscripts are significantly different $(P<0.05)$.

Values based on a cycle duration of 8.6 days (Swierstra, 1968a).

The unstained $20 \mu \mathrm{m}$ Epon sections were examined under Nomarski optics to determine the maximum diameter of all spherical nuclei of cells (Johnson et al., 1980; Johnson and Neaves, 1981). By adjusting the focus control in an up and down movement, the maximum diameters of nuclei embedded in the thick Epon were located and measured. The nuclear diameters for the Sertoli cells and type A spermatogonia were estimated as the average of the height and width measurements due to their irregular and oval shapes, respectively (Johnson, 1985). At least 50 nuclei per cell type per boar were measured using a computerized digitizing unit directly attached to the microscope with Nomarski optics. Measurements were randomized among stages of the cycle of the seminiferous epithelium where each germ cell was present. The number of cells of a given cell type per testis, including Sertoli cells, was calculated as the product of percentage nuclei in parenchyma, parenchymal volume, and histologic correction factor for section thickness and nuclear diameter (Weibel and Paumgartner, 1978) divided by the average volume of a single nucleus of that cell type (Kennelly and Foote, 1964; Amann, 1970; Johnson et al., 1984a). The average volume of a single nucleus was calculated using the formula for a sphere (Johnson, 1985). No correction factor for shrinkage was applied as glutaraldehyde-fixed and osmicated-fixed tissue placed in Epon undergo negligible shrinkage during histological processing (Johnson and Neaves, 1981; Johnson et al., 1983), and no signs of shrinkage were evident in Epon-embedded boar tissues in the present study.

\section{Preparation of homogenates and identification and enumeration of different classes of spermatid nuclei}

Fixed testicular parenchyma was blotted on a piece of dry dental wax to remove surface buffer without draining fluid from the depths of the tissue. Approximately $0.4 \mathrm{~g}$ of the tissue was homogenized in a Warring blender for $6 \mathrm{~min}$ in $100 \mathrm{ml}$ of fluid containing $150 \mathrm{mmol} \mathrm{NaCl} 1^{-1}, 0.05 \%(\mathrm{v} / \mathrm{v})$ Triton X-100, and $3.8 \mathrm{mmol} \mathrm{NaN} \mathrm{I}^{-1}$ (Amann and Lambiase, 1969; Johnson and Thompson, 1983). This preparation produced a cell suspension of all germ cell types from which various types of elongated spermatid could be enumerated by phase-contrast cytometry (Johnson and Thompson, 1983). The criteria used in identifying the spermatids $\left(\mathrm{Sa}, \mathrm{Sb}_{1}, \mathrm{Sb}_{2}, \mathrm{Sc}, \mathrm{Sd}_{1}\right.$, and $\mathrm{Sd}_{2}$ ) ranged from the stage of acrosome development, appearance of structures such as the manchette and annulus, movement of the mitochondria, and formation of the cytoplasmic droplet (Johnson et al., 1981). The identity of these nuclei was verified by comparing them to their counterparts viewed in situ in $0.5 \mu \mathrm{m}$ histological sections under phase-contrast microscopy. Duplicate counts were made using a haemocytometer for each boar.

Germ cell ratios and daily sperm production based on various germ cells and Sertoli cell index

The ratio of type $B$ spermatogonia to type A spermatogonia was calculated by dividing the number of type $B$ spermatogonia by the number of type A spermatogonia. Similarly, the ratios of pachytene spermatocytes to type $A$ spermatogonia and spermatids with round nuclei to type $A$ spermatogonia were determined using the same procedure as stated above. Estimates of these ratios represent indices of degeneration of germ cells during the spermatogenic cycle.

Daily sperm production was estimated as the product of the number of germ cells of a given type per testis and the theoretical yield (total possible number of sperm produced per given cell type) divided by the lifespan of that cell type (Kennelly and Foote, 1964; Amann, 1970, 1981; Johnson et al., 1984a). For leptotene and pachytene spermatocytes, and spermatids with round nuclei, the theoretical yields were 4,4 , and 1 , and their lifespans were 1.67, 7.64, and 6.06 days, respectively. Lifespans were derived as the sums of the duration of stages of the cycle in which the given cell types were present (Swierstra, 1968a). Daily sperm production based on Sc, Sd , and $\mathrm{Sd}_{2}$ spermatids characteristic of stages IV-VIII was calculated by dividing the number of these spermatid nuclei, enumerated in the homogenate, by their lifespan (5.86 days) based on an 8.6 day cycle (Swierstra, 1968a). It should be noted 

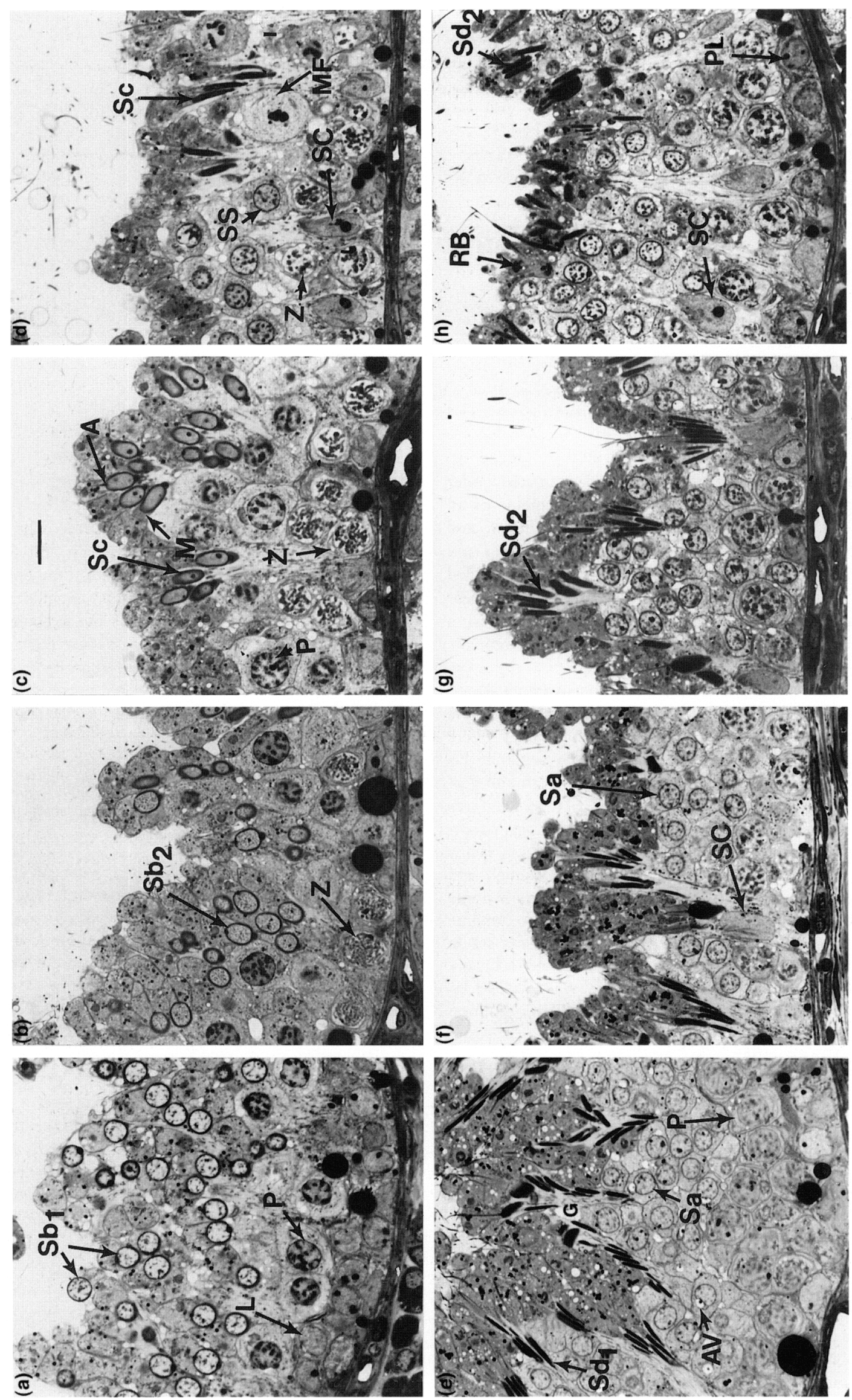

.
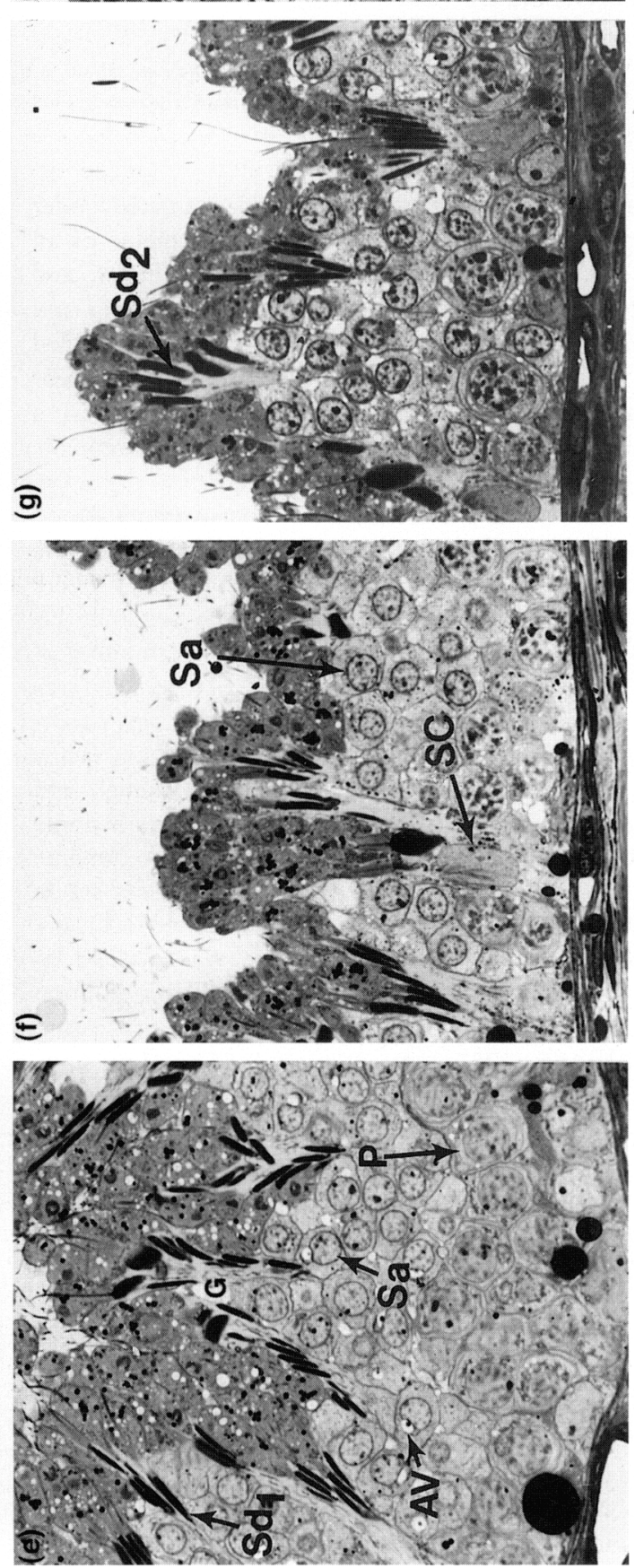
that the time divisor of 5.86 days differs slightly from 6.19 days previously calculated by Amann et al. (1974, 1976). The disparity (resulting in a 5\% difference) arises from slight variations in the numerical values of frequency of stages and therefore relative duration of the stages of the cycle of seminiferous epithelium obtained in the two studies. The histometric daily sperm production was evaluated by obtaining estimates based on round spermatids; haemocytometric counts of Sa spermatids were conducted in homogenates of fixed tissues (Sa spermatids are present in stages V-VIII and I), and by pooling values from the two techniques, daily sperm production per boar was estimated for each breed. daily sperm production per gram of testicular parenchyma was obtained by dividing the daily sperm production per boar by the parenchymal mass. Differences in daily sperm production based on various germ cell types reflected germ cell degeneration during spermatogenesis. The amount of degeneration that occurred at various steps of spermatogenesis, were estimated by pooling values of daily sperm production per gram of testis for the three breeds and using the average to calculate the sequential values. For instance, the germ cell loss that occurred during cellular transformation of leptotene to pachytene spermatocytes was determined by subtracting the daily sperm production per gram based on pachytene spermatocytes from the daily sperm production per gram based on leptotene spermatocytes divided by the daily sperm production per gram based on leptotene spermatocytes (Johnson et al., 1983).
The number of germ cells accommodated by a single Sertoli cell per testis was determined by dividing product $I$ by product 2 for each germ cell type (Johnson, 1986a). Product 1 was equal to the number of each germ cell type per testis (Johnson and Thompson, 1983; Johnson, 1985) multiplied by 8.6 days, the duration of the cycle in the boar (Swierstra, 1968a). Product 2 was equal to the number of Sertoli cells per testis (determined histometrically) multiplied by the lifespan of the germ cell type being compared.

\section{Statistical analyses}

One-way analysis of variance and Student-Newman procedure were used to identify breed differences in parameters evaluated (Sokal and Rohlf, 1969; SAS Institute, 1985). Correlation coefficients among various parameters of spermatogenesis were determined for each breed. The coefficients for most parameters were similar among breeds and data were pooled across breeds (Sokal and Rohlf, 1969).

\section{Results}

\section{Relative frequencies and duration of the stages of the seminiferous epithelial cycle}

Apart from stage I, there were no significant differences $(P>0.05)$ in the relative frequencies of stages among breeds

Fig. 1. Representative cross-sections of the seminiferous tubules taken from testes of Whitecross, Meishan and West African boars showing the eight stages of the cycle of seminiferous epithelium viewed under brightfield microscopy in toluidine blue-stained ( $0.5 \mu \mathrm{m})$ sections. Scale bar represents $10 \mu \mathrm{m}$. (a) Stage I: two generations of primary spermatocytes (leptotene and pachytene) and one generation of spermatids ( $\mathrm{Sb}_{1}$ or cap phase) are present. These spermatids are characterized by spherical nuclei, developing tails, attached acrosomal cap, and Golgi apparatus situated near the distal end of the head cap. The leptotene spermatocytes $(\mathrm{L})$ are located close to the basement membrane while the pachytene spermatocytes $(\mathrm{P})$ are located above the base. The oval-shaped type A spermatogonia with distinct clumps of chromatin in the nucleus are located along the basement membrane. (b) Stage II: Stage II is characterized by two generations of primary spermatocytes (zygotene (Z) and pachytene) and partially elongated spermatids $\left(\mathrm{Sb}_{2}\right)$ with extended acrosomal knobs. (c) Stage III: Acrosomic phase (Sc) spermatids continue their elongation and nuclear condensation with the manchette $(M)$ and annulus $(A)$ becoming very distinct. Zygotene spermatocytes $(Z)$ have larger nuclei with smaller spaces between heavy chromatin clumps than do the late leptotene spermatocytes. Pachytene spermatocytes (P) are still present. The type A spermatogonia continue to line the basement membrane. (d) Stage IV: Stage IV is characterized by the presence of zygotene primary spermatocytes $(\mathrm{Z})$, mitotic figures $(\mathrm{MF})$, secondary spermatocytes (SS), and Sc spermatids $(\mathrm{Sc})$. The nuclei of the secondary spermatocytes are spherical with distinct nuclear membranes and evenly distributed chromatin fragments. They are $14 \%$ larger than the round spermatids of subsequent stages and $30 \%$ smaller than their progenitors (pachytene spermatocytes of previous stages). SC: Sertoli cell. (e) Stage V: Two generations of spermatids are present. The newly formed round spermatids (Sa) with distinct Golgi apparatus (G), acrosomic vesicle (AV), and $\mathrm{Sd}_{1}$ spermatids whose morphological transformation continues, forming bundles that are embedded in the seminiferous epithelium and are continuously being shifted to a more apical position. The pachytene primary spermatocytes $(P)$ resulting from the zygotene spermatocytes of Stage IV, have a larger nucleus, and characteristic bouquet chromatin filaments. Intermediate spermatogonia are located near the basement membrane. (f) Stage VI: Type B spermatogonia make their first appearance in the cycle and are located among type A spermatogonia but not resting on the basement membrane. The acrosomic vesicle starts its indentation process on the nuclear envelope of Sa spermatids. The manchette has become less distinct in the $\mathrm{Sd}_{1}$ spermatids whose bundles are now located in the luminal half of the seminiferous epithelium. ( $\mathrm{g}$ ) Stage VII: This stage is characterized by the presence of type B spermatogonia which will undergo mitosis at the end of this stage to give rise to preleptotene primary spermatocytes in Stage VIII. Pachytene primary spermatocytes and Sa spermatids are present, and Sd, spermatids make their final migration to the lumen. (h) Stage VIII: Stage VIII is identified by the presence of a concentric layer of $\mathrm{Sd}_{2}$ spermatids lining the lumen. Characteristic features peculiar to $\mathrm{Sd}_{2}$ spermatids include an enlarged middle piece, attached cytoplasmic droplet, and its integrated annulus. The newly formed preleptotene spermatocytes ( $\mathrm{PL}$ ), though morphologically similar to $\mathrm{B}$ spermatogonia, are more numerous and smaller. The acrosomic granule continues its development in Sa spermatids while the pachytene spermatocytes retain characteristics similar to those of previous stages. Residual bodies $(\mathrm{RB})$ resulting from spermiation of $\mathrm{Sd}_{2}$ spermatids are present near the luminal surface and in transit toward the base of the tubule within the cytoplasm of the Sertoli cells.

Sertoli cells are present at all of the stages and appear in columns within the seminiferous epithelium. The nuclei of Sertoli cells are pear-shaped with a large nucleolus and, while some rest on the basement membrane, others are located in the adluminal compartment. Spermatids (Sc, Sd ${ }_{1}$, $\mathrm{Sd}_{2}$ ) are oriented between lateral borders of adjacent Sertoli cells or in the apex of individual Sertoli cells, but this arrangement changes constantly with the stage of the cycle. 
(Table 1). The most frequent cellular association was stage I for the Whitecross and Stage VI for the Meishan and West African. However, the least frequent association, stage III, was common to the Meishan and West African boars. For the Whitecross it was stage $V$. The average relative frequencies pooled from data on the three breeds show that the most common and the least common associations were stages VI and III, respectively. Typical cross-sections of the seminiferous tubules (Fig. 1) in the three breeds extensively displayed one cellular association. However, a few tubules exhibited multiple cellular associations (Fig. 2a). A stage VI tubule is shown (Fig. 2b). Various types of spermatid at different stages of development as viewed by phase-contrast microscopy are also shown (Fig. 3).

\section{Daily sperm production and germ cell degeneration}

The daily sperm production per boar based on different germ cell types (Table 2 ) was significantly $(P<0.05)$ higher in the Whitecross than in the Meishan or West African boars. The daily sperm production per gram of parenchyma did not differ significantly $(P>0.05)$ between breeds (Fig. 4). While daily sperm production per gram was negatively correlated $(P>0.05)$ with testis mass and with the ratio of round spermatids to A spermatogonia (Table 3), it was unrelated to the number of Sertoli cells per gram of testis $(r=0.09)$.

Germ cell ratios based upon the most, and the least, advanced germ cells represent rates of cellular yield or degeneration and measure efficiency of spermatogenesis. There was a trend for these ratios or indices to be higher in the Meishan boars, indicating less degeneration in that breed (Fig. 5), but the differences were not statistically different among breeds. The spermatid yield per A spermatogonium was correlated $(P<0.05)$ with the spermatid:Sertoli cell ratio but was unrelated to daily sperm production $\left(R^{2}=5.8 \%\right)$, numbers of Sertoli cells per testis, or per gram of parenchyma.

The total number of all germ cells accommodated by a single Sertoli cell in Stage VIl of the cycle (Whitecross: $19.91 \pm 1.62$; Meishan: 39.08 \pm 5.07; West African: $15.81 \pm 2.43$ ), and individual cell types supported by a single Sertoli cell (except with A spermatogonia) were significantly $(P<0.05)$ higher in the Meishan than in the Whitecross or West African boars (Fig. 6). The number of spermatids or total germ cells per Sertoli cell in stage VII were correlated $(P<0.05)$ with the ratio of spermatids per type $A$ spermatogonium but were unrelated $(P>0.05)$ to daily sperm production (Table 3 ).

Within, and among, breeds, there were no significant differences $(P>0.05)$ in daily sperm production per gram at different steps of the long meiotic prophase (Fig. 4), that is between the leptotene and pachytene stage. During the first and second reduction divisions (between the step from pachytene spermatocytes to round spermatid stage), breeds did not differ significantly $(P>0.05)$ in the degree of degeneration. During this period, significant germ cell loss occurred in all breeds $26.56 \pm 0.02 \%, \quad 34.38 \pm 0.03 \%$, and $35.24 \pm 0.06 \%$ for Whitecross, Meishan and West African, respectively; mean loss $=32.6 \pm 0.1 \%$ ). A less pronounced germ cell degeneration also occurred during spermiogenesis, and the degree of loss was again similar in all three breeds (mean loss $=8.6 \pm 0.1 \%$ ).


Fig. 2. Representative cross-sections of seminiferous tubules taken from testes of Whitecross, Meishan or West African boars showing in (a) a tubule with two cellular associations. $\mathrm{Sb}_{2}$ and $\mathrm{Sc}$ spermatids characteristic of stages II and III, respectively, are present. Other germ cells common to the two stages are zygotene $(\mathrm{Z})$ and pachytene $(\mathrm{P})$ spermatocytes. (b) Stage VI tubule sectioned at $20 \mu \mathrm{m}$ and viewed, unstained, using Nomarski optics. Maximum diameters of nuclei of germ, Sertoli and Leydig cells were obtained by focusing up and down and were read directly on a digitizing unit attached to the microscope. Round spermatids $(\mathrm{R})$ and pachytene spermatocytes $(\mathrm{P})$ are observed. Scale bar represents $10 \mu \mathrm{m}$. 


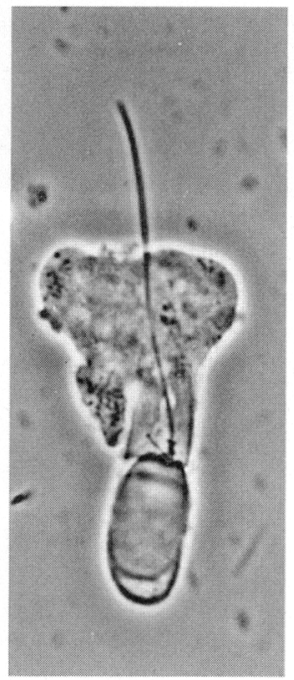

$\mathrm{Sd}_{1}$

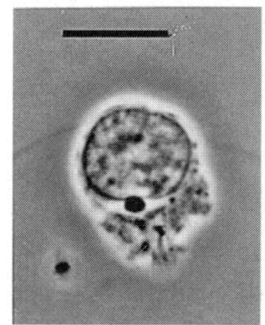

Sa

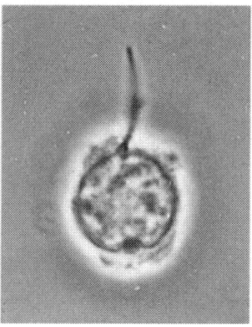

$\mathrm{Sb}_{1}$

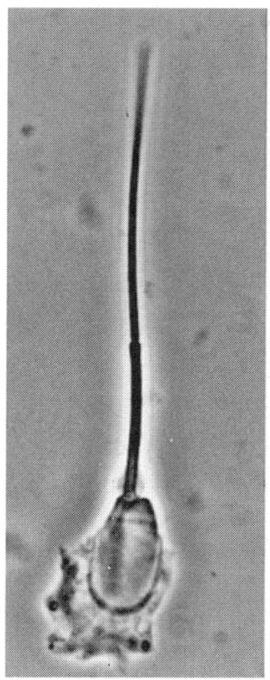

$\mathrm{Sd}_{2}$

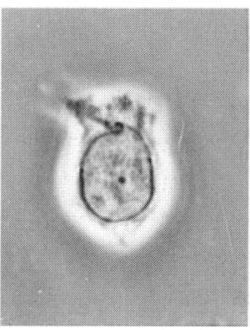

$\mathrm{Sb}_{2}$

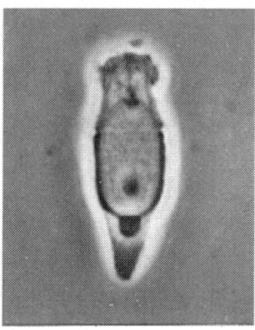

Sc

Fig. 3. Various types of spermatid at different phases of development during spermiogenesis obtained from representative testes of Whitecross, Meishan and West African boars viewed by phase contrast microscopy of testicular homogenate. Sa spermatids are round and characterized by little acrosomal development and acrosomic granule. $\mathrm{Sb}_{1}$ spermatids have a distinct acrosomal cap and emerging tail. $\mathrm{Sb}_{2}$ spermatids are characterized by elongated nuclei. Sc spermatids have a distinct manchette with elongated nuclei which later starts condensing and an extended acrosomal knob. Sd spermatids are identified by the presence of the annulus near the head on the developing tail. $\mathrm{Sd}_{2}$ spermatids have an enlarged middle piece coupled with the presence of mitochondria in that region. In addition, the proximal droplet has formed. Scale bar represents $10 \mu \mathrm{m}$.

\section{Discussion}

The breed variation observed in the number and function of Sertoli cells and in the number and yield of $\mathrm{A}$ spermatogonia are obvious contributors to the differences in daily sperm production evident in the pig breeds studied. These in turn, could explain the reported breed variations in the number of spermatozoa in ejaculates. The boars analysed in this study were raised in different locations (Whitecross and Meishan: Nebraska, West African: Nigeria). As a result, the effect of environmental factors (for example temperature or humidity), management, nutrition and disease on sperm production and other testicular functions cannot be ignored. While it was not possible to control these factors, we acknowledge the potential impact they may have had on some of the testicular parameters evaluated in this study.

In the present study, parenchymal mass contributed more to the variability in daily sperm production $\left(R^{2}=94 \%\right)$ than did any other factor under consideration. Thus, the daily sperm production obtained for these breeds varied in proportion to their testicular sizes, the ratio of this variance being 4:2:1 for the Whitecross:Meishan:West African, respectively. Testicular size is related to the age of the animal and is influenced markedly by breed or strain (Schinckel et al., 1983, 1984). A positive biological relationship between body mass and testicular mass has been reported in rats (Berndtson and Thompson, 1990), and this was supported by the highly significant correlation obtained in the study reported here $(r=0.94$; $P<0.01$ ) and that of Egbunike et al. (1975) for German Landrace boars $(r=0.78 ; P<0.01)$. However, despite these observations, investigators (Berndtson and Thompson, 1990; Hochereau-de Reviers $e t$ al., 1990) still advocate caution on the applicability of this relationship in data interpretation, since other factors could make substantial contributions to differences in testicular size, especially among animals of similar age. Furthermore, low correlations between body mass and daily sperm production, as reported in several species (Kennelly, 1960; Almquist and Amann, 1961; Orgebin-Crist, 1968), 
Table 2. Age, body mass, testicular characteristics and daily sperm production in three breeds of boar

\begin{tabular}{|c|c|c|c|}
\hline Parameters & Whitecross & Meishan & West African \\
\hline$n$ & 5 & 5 & 5 \\
\hline Age (days) & $346.4 \pm 1.89$ & \pm 2.88 & \pm 1.75 \\
\hline Body mass $(\mathrm{kg})$ & $133.4 \pm 5.46^{\mathrm{a}}$ & $77.76 \pm 2.02^{b}$ & $34.01 \pm 0.96^{\circ}$ \\
\hline Paired parenchymal mass $(\mathrm{g})$ & $497.78 \pm 34.74^{\mathrm{a}}$ & $247.24 \pm 17.17^{b}$ & $133.27 \pm 10.05^{\circ}$ \\
\hline Testis mass as a percentage of body mass & $4.1 \pm 0.3$ & $3.4 \pm 0.2$ & $4.2 \pm 0.2$ \\
\hline Type A spermatogonia per boar $\left(10^{-9}\right)$ & $5.63 \pm 0.87^{\mathrm{a}}$ & $1.51 \pm 0.20^{\mathrm{b}}$ & $1.36 \pm 0.30^{\circ}$ \\
\hline Type A spermatogonia per gram & $11.45 \pm 1.8$ & $6.13 \pm 0.7$ & $9.88 \pm 1.81$ \\
\hline Number of Sertoli cells per boar $\left(10^{-9}\right)$ & $14.45 \pm 1.33^{\mathrm{a}}$ & $3.87 \pm 0.59^{c}$ & $5.01 \pm 0.34^{\mathrm{b}}$ \\
\hline Number of Sertoli cells per gram & $29.32 \pm 2.71^{b}$ & $15.68 \pm 2.06^{\mathrm{c}}$ & $38.45 \pm 3.78^{\prime \prime}$ \\
\hline \multicolumn{4}{|l|}{ Daily sperm production $\left(10^{-9}\right)$} \\
\hline Based on pachytene spermatocytes & $17.93 \pm 1.70^{\mathrm{a}}$ & $9.46 \pm 0.61^{b}$ & $5.63 \pm 0.66^{\circ}$ \\
\hline \multicolumn{4}{|l|}{ Based on round spermatids } \\
\hline (a) histometric technique & $14.35 \pm 1.78^{\mathrm{a}}$ & $7.39 \pm 0.52^{b}$ & $4.26 \pm 0.59^{\circ}$ \\
\hline (b) homogenate method & $11.99 \pm 1.61^{\mathrm{a}}$ & $4.98 \pm 0.42^{b}$ & $2.88 \pm 0.36^{\mathrm{c}}$ \\
\hline pooled values of (a) and (b) & $13.17 \pm 1.37^{\mathrm{a}}$ & $6.18 \pm 0.42^{b}$ & $3.57 \pm 0.36^{\circ}$ \\
\hline Based on elongated spermatids & $12.46 \pm 1.47^{\mathrm{a}}$ & $6.04 \pm 0.52^{b}$ & $2.91 \pm 0.33^{\mathrm{c}}$ \\
\hline $\begin{array}{l}\text { Daily sperm production per gram }\left(10^{-0}\right) \\
\text { based on elongated spermatids }\end{array}$ & $24.77 \pm 1.43$ & $24.47 \pm 1.26$ & $21.73 \pm 1.95$ \\
\hline
\end{tabular}

Values are means \pm SEM.

a.b,c Means within rows with different superscripts are significantly different $(P<0.05)$.

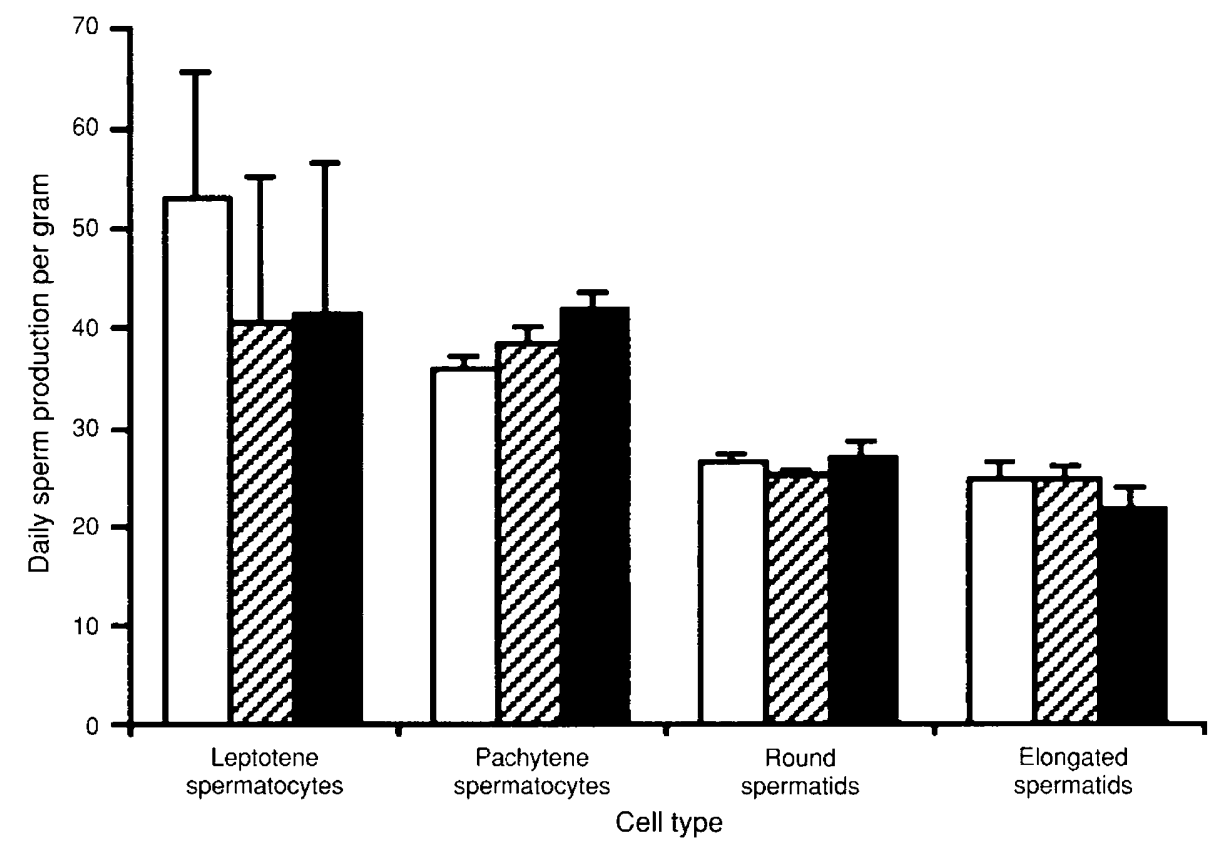

Fig. 4. Daily sperm production per gram of parenchyma based on different germ cell types in adult ( $\square$ ) Whitecross; ( $\square$ ) Meishan and ( $\square$ ) West African boars. Differences between estimates among breeds at consecutive developmental steps reflect germ cell degeneration. While there was no significant difference $(P>0.05)$ among breeds in germ cell loss between the leptotene primary spermatocytes and round spermatids, there seemed to be a trend in germ cell loss along these developmental steps. The similarity in values of daily sperm production per gram based on round spermatids and elongated spermatids indicates the occurrence of minimal degeneration during spermiogenesis.

suggest that testicular mass or sperm production may not be predicted accurately from body mass or from the age of the animal (Amann, 1970).
When based on elongated spermatids and spermatids with round nuclei, respectively, our daily sperm production values for the Whitecross $\left(12.6 \pm 1.47 \times 10^{9}\right.$ and $\left.13.17 \pm 1.37 \times 10^{9}\right)$ 
Table 3. Correlation coefficients of testicular characteristics across all three breeds of boar $(n=15)$

\begin{tabular}{|c|c|c|c|c|c|c|c|c|c|}
\hline & $\begin{array}{c}(1) \\
\text { Body } \\
\text { mass }\end{array}$ & $\begin{array}{c}(2) \\
\text { Parenchymal } \\
\text { mass }\end{array}$ & $\begin{array}{c}(3) \\
\text { DSP per } \\
\text { boar }\end{array}$ & $\frac{(4)}{\mathrm{DSP}} \mathrm{g}^{-1}$ & $\begin{array}{c}\text { (5) } \\
\text { Spermatid/A } \\
\text { spermatogonia }\end{array}$ & $\begin{array}{l}\text { (6) } \\
\text { Number of } \\
\text { Sertoli cells }\end{array}$ & $\begin{array}{c}(7) \\
\text { Number of A } \\
\text { spermatogonia }\end{array}$ & $\begin{array}{c}\text { (8) } \\
\text { Spermatid/ } \\
\text { Sertoli cell }\end{array}$ & $\begin{array}{c}\text { (9) } \\
\text { Sertoli } \\
\text { cell } \mathrm{g}^{-1}\end{array}$ \\
\hline (I) & - & & & & & & & & \\
\hline (2) & $0.95 * *$ & 一 & & & & & & & \\
\hline (3) & $0.92 * *$ & $0.97 * *$ & - & & & & & & \\
\hline (6) & $0.74 *$ & $0.87^{* *}$ & $0.87 * *$ & 0.04 & -0.52 & - & & & \\
\hline (7) & $0.86^{*}$ & $0.85 * *$ & $0.88^{* *}$ & 0.17 & -0.60 & $0.95 * *$ & - & & \\
\hline (8) & 0.05 & 0.00 & 0.01 & 0.13 & $0.62 *$ & -0.43 & -0.26 & - & \\
\hline (9) & 0.34 & $0.94 * *$ & $0.94 * *$ & 0.09 & -0.11 & $0.97^{* *}$ & $0.94 * *$ & -0.26 & - \\
\hline
\end{tabular}

DSP: daily sperm production.

$* P<0.05 ; * P<0.01$.

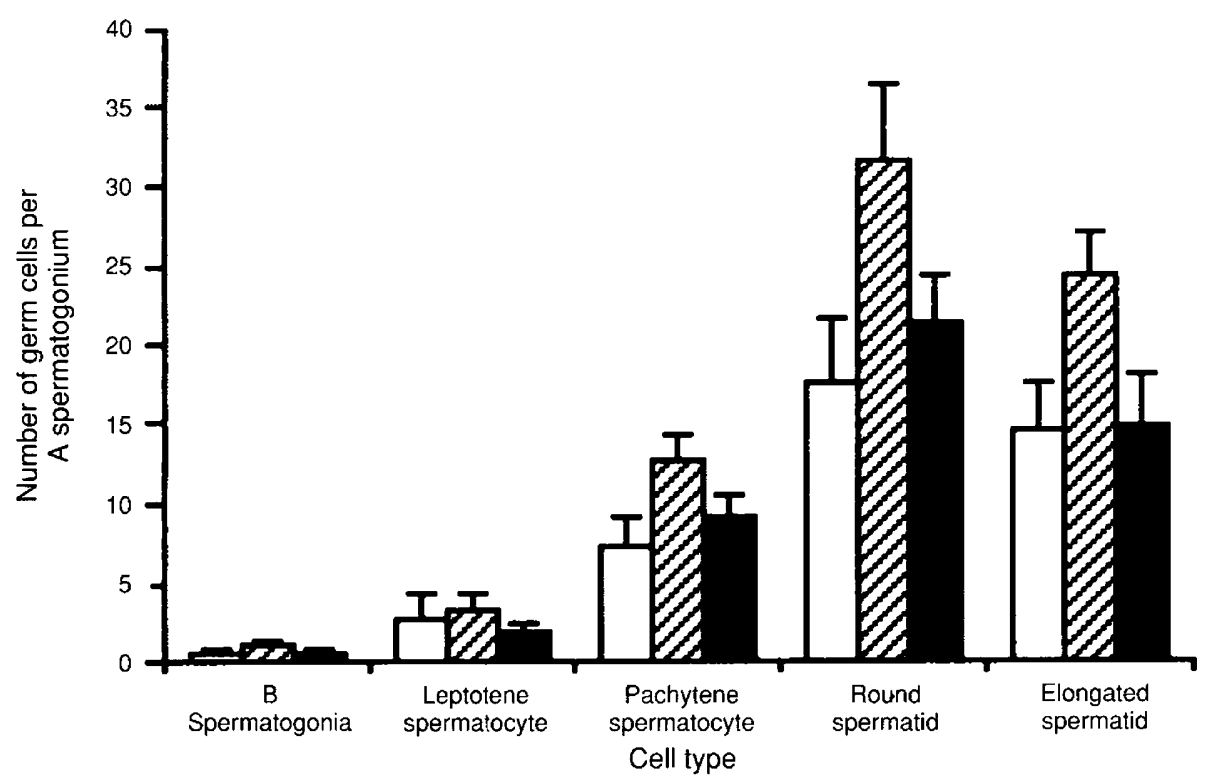

Fig. 5. The yield of germ cells per type A spermatogonium (index of germ cell degeneration) from testes tended to be higher in the (घ) Meishan than in the ( $\square$ ) Whitecross or ( $\square$ ) West African boars, but differences were not statistically significant between breeds.

closely agrees with $11.53 \times 10^{9}$ recorded for German Landrace boars (Egbunike and Steinbach, 1976) of similar live mass $(130-139 \mathrm{~kg})$ and testicular mass $(568 \mathrm{~g})$ but lower than $16.5 \times 10^{9}$ and $17.8 \times 10^{9}$ obtained for 11 -month-old Yorkshire and Lacombe boars, respectively, using a similar analytic method (Swierstra, 1968b). The daily sperm production for the Meishans $\left(6.04 \pm 0.52 \times 10^{9}\right)$ was similar to $5.5 \times 10^{9}$ reported for Piau boars (Franca, 1992) using a Sertoli cell index to calculate daily sperm production. The boars used in their study had similar testicular masses $(221 \mathrm{~g})$ but were older (16.7 months) than the Meishan boars (7.2 months) in the present study. This confirms that pigs of the Meishan breed mature earlier; they attain puberty as early as 75 days of age although sexual maturity is not reached until 120 days of age (Harayama et al., 1991). The daily sperm production value $\left(2.91 \pm 0.33 \times 10^{9}\right)$ obtained in the current study for West
African boars was higher than estimates $\left(0.96 \times 10^{9}\right.$ and $1.14 \times 10^{9}$ ) previously reported for West African boars of similar live mass and age (Egbunike and Steinbach, 1976).

Daily sperm production per gram, a measure of efficiency of spermatogenesis (Amann, 1970), was similar for the three breeds under study. Swierstra (1970) reported daily sperm production per gram ranging from $23.6 \times 10^{6}$ to $24.1 \times 10^{6}$ for Yorkshire and Lacombe boars, respectively. Egbunike et al. (1975) obtained a value of $25.89 \times 10^{9}$ for Landrace boars, while that for Piau boars was determined as $27.3 \times 10^{\circ}$ (Franca, 1992). In the present study, we obtained $24.47 \pm 1.26$ and $24.77 \pm 1.43 \times 10^{6}$ for the Meishan and Whitecross, respectively and $21.73 \pm 1.95 \times 10^{\circ}$ for the West African, indicating no significant difference among breeds. In the studies cited above, the daily sperm production per gram was fairly constant within breed and similar among boars of different breeds, 


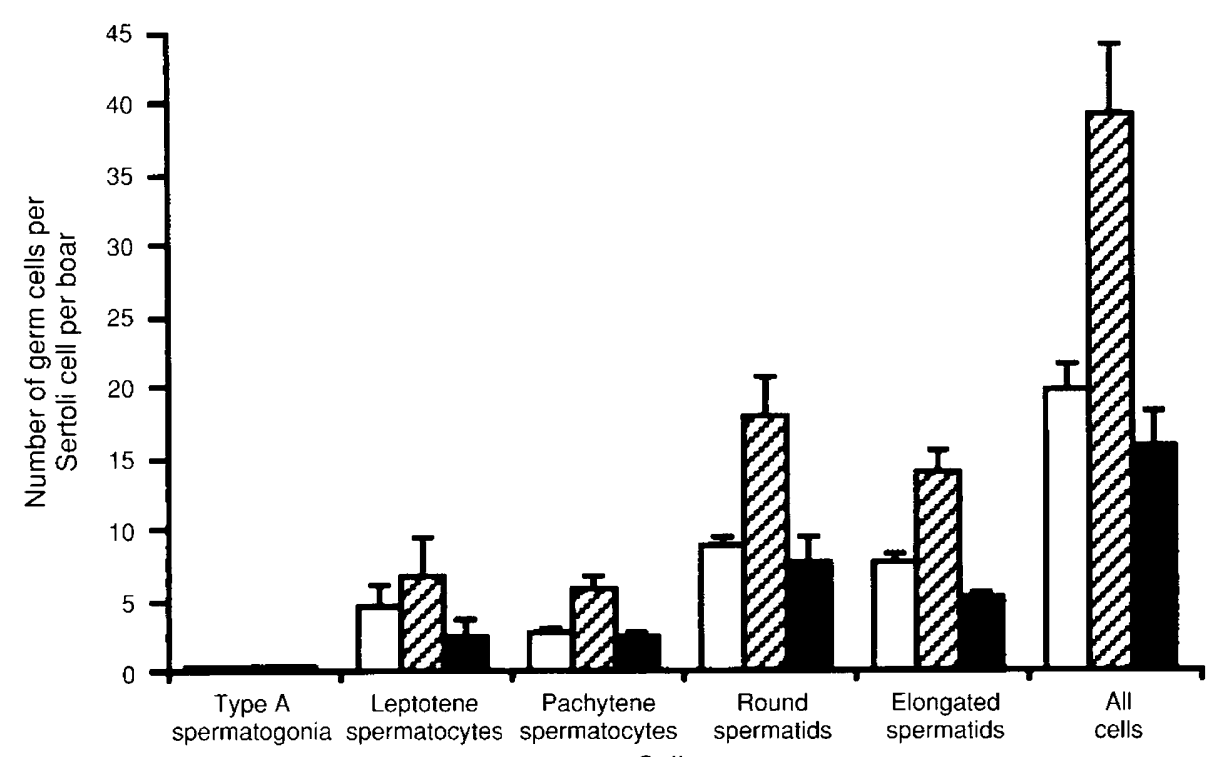

Cell type

Fig. 6. The number of germ cells per Sertoli cell in stage VII of the cycle of seminiferous epithelium from the testes of Whitecross, Meishan and West African boars. At all developmental steps or combining all germ cells, the efficiency of Sertoli cell function was higher in the (Ø) Meishan than in the ( $\square$ ) Whitecross or ( $\square$ ) West African breed boars.

thus the total number of spermatozoa produced by each boar/breed depended on the size of the testis. However, it is noted that the similar daily sperm production per gram was obtained despite breed differences in number and yield of $\mathrm{A}$ spermatogonia.

Interspecies comparisons present a different picture. Daily sperm production per gram values have been reported for rams, $12.2 \times 10^{6}$ (Ortavant et al., 1977), rats, $21.2 \times 10^{6}$ (Johnson et al., 1980), stallions, $18.8 \times 10^{6}$ (Johnson and Neaves, 1981), dairy bulls, $17.7 \times 10^{6}$ (Almquist and Amann, 1961), buffalo, $32 \times 10^{6}$ (Verma et al., 1965) and humans, 4-6 $\times 10^{6}$ (Johnson et al., 1981). Thus, it would appear that boars produce spermatozoa with almost the same efficiency as rats, and that they are more efficient producers than man and most domestic animals with the exception of buffalo (Amann, 1970). These differences in sperm production rates between species arise from variations in yield of spermatozoa per spermatogonium coupled with differences in duration of the cycle of seminiferous epithelium (Swierstra, 1968a; Johnson, 1986b).

The yield of spermatids per type A spermatogonium is a measure of germ cell degeneration. A low yield of spermatids per spermatogonium indicates cellular degeneration or failure of normal cell division during spermatogenesis. The same measure could be extended to the yield of other, younger germ cell types (spermatids with spherical nuclei and pachytene spermatocytes) per type A spermatogonia. Regardless of the stage of spermatogenesis, the twofold germ cell yield in the Meishan over the Whitecross or West African boars is indicative of less degeneration occurring in that breed. Although this difference was not significant among breeds (this may have resulted from the small number of animals sampled), the low index of degeneration in the Meishan contributed substantially to its intermediate daily sperm production value. However, with the non-significant relationship obtained in these germ cell ratios between breeds, it is not surprising that rates of germ cell yield or degeneration contributed only slightly $\left(R^{2}=5.8 \%\right)$ to the variability in daily sperm production among boars and was unrelated to parenchymal mass $(P>0.05)$, daily sperm production per gram $(P>0.05)$, and Sertoli cells per testis $(P>0.05)$.

Among other factors associated with variations in daily sperm production among boars was the number of type $A$ spermatogonia per testis. The number of $A$ spermatogonia was highly and positively $(P<0.01)$ correlated with the number of Sertoli cells per testis $(r=0.95)$, parenchymal mass $(r=0.88)$, and accounted for $77 \%$ variability in daily sperm production among breeds. The number of committed spermatogonia (number of spermatogonia) which initiate the spermatogenic cycle and eventually determine the quantity of spermatozoa produced is influenced by the population of type A spermatogonia in the testis. This number of spermatogonia depends on (i) the number of stem cells per testis, (ii) the scheme of stem cell renewal, (iii) the number of cell divisions from stem cells to primary spermatocytes (Hochereau-de Reviers, 1981) and (iv) the degeneration index of spermatogonial subtypes (Huckins, 1978; Johnson, 1991a, b). Given that (ii), (iii) and (iv) are similar among the three breeds, the higher population of A spermatogonia in the Whitecross is partly responsible for its higher daily sperm production. In horses, seasonal fluctuations in the numbers of type A spermatogonia have been implicated as an important factor modulating the quantitative production of spermatozoa in the breeding and nonbreeding seasons (Johnson, 1985). Furthermore, the physiological relationship between number of Sertoli cells or parenchymal mass and daily sperm production in horses is believed to be mediated by the number or yield of type A spermatogonia per testis (Johnson et al., 1994). 
The Sertoli cell regulates spermatogenesis in several ways. Thus the Sertoli cell may prove to be an important factor in establishing a ceiling in the rate of sperm production in bulls and stallions (Johnson and Thompson, 1983; Johnson et al., 1984a; Berndtson et al., 1987). A possible means by which Sertoli cells can place this limit on the spermatogenic potential is by controlling testis size (Kluin et al., 1984) or modulating type A spermatogonial populations (Hochereau-de Reviers, 1981; Johnson, 1991b). Thus in the present study, the number of Sertoli cells was highly $(P<0.01)$ correlated with parenchymal mass $(r=0.87)$, A spermatogonia $(r=0.95)$ and daily sperm production $(r=0.87)$. The same relationships have been observed in humans (Johnson et al., 1984a), bulls (Berndtson et al., 1987), horses (Johnson et al., 1994) and rams (Hochereau-de Reviers et al., 1990). It is likely that the breed differences obtained in the total number of Sertoli cells per testis may have induced similar variations in germ cell production. Hence, the Whitecross with the highest numbers of Sertoli cells had the heaviest testes, largest number of A spermatogonia, and therefore produced the highest number of spermatozoa. Considering the three breeds, the number of Sertoli cells was responsible for $76 \%$ variability in daily sperm production among boars.

The spermatid:Sertoli cell ratio is a measure of the work load and function of the Sertoli cell (Johnson et al., 1984a; Johnson, 1986a), which has been used extensively in quantifying spermatogenesis (Rowley and Heller, 1971; Berndtson and Igboeli, 1989; Franca, 1992). This ratio is based on the assumption that relative changes in daily sperm production would alter the number of spermatids supported by the stable Sertoli cell population (Berndtson, 1977; Russell and Peterson, 1984). Our data reveal that germ cell:Sertoli cell ratios at different steps of spermatogenesis and combined germ cells per Sertoli cell were significantly higher $(P<0.05)$ in the Meishan than in Whitecross or West African boars. This implies that Sertoli cells in Meishans either have greater work load or are more efficient in supporting spermatogenesis. It is interesting to note that the number of spermatids per Sertoli cell $(P<0.05)$ and the total number of germ cells supported by Sertoli cells in stage VII were related to the spermatid yield per type A spermatogonia. This result suggests that in Meishans, in which the degeneration index was lowest, more germ cells were made available and were accommodated by a smaller Sertoli cell population. This explains the almost twofold increase in work load for Sertoli cells in Meishans in contrast to the other breeds. This observation is similar to the reported seasonal increases in the work load of Sertoli cells in horses (Johnson, 1986a) during the breeding season when daily sperm output is increased (Johnson and Thompson, 1983).

Meishan boars have increased concentrations of serum FSH, LH and testosterone from birth to puberty (Lunstra et al., 1992), and serum concentrations of these hormones remain raised in mature Meishan boars compared with values in boars of common US breeds (Borg et al., 1993; Wise et al., 1995). FSH is the most markedly increased serum hormone (four to nine times higher) in Meishan boars, while serum inhibin tends to be lower in Meishans than in boars of common US breeds (Borg et al., 1993; Wise et al., 1995). While serum hormones were not evaluated in the Meishan and Whitecross boars that provided testes for the current study, hormone concentrations were assessed in other mature Meishan and Whitecross boars from the same bloodlines. In these related boars, Meishan boars had significantly higher serum FSH (554 \pm 50 versus $102 \pm 8 \mathrm{ng}$ $\left.\mathrm{ml}^{-1}\right)$, serum LH $\left(1.3 \pm 0.2\right.$ versus $\left.0.2 \pm 0.1 \mathrm{ng} \mathrm{ml}^{-1}\right)$, and serum testosterone ( $14.5 \pm 0.6$ versus $2.6 \pm 0.2 \mathrm{ng} \mathrm{ml}^{-1}$, respectively) than did Whitecross boars (Wise et al., 1995). Although daily sperm production per gram did not differ between Whitecross and Meishan boars, the number of Sertoli cells per gram was lower $(P<0.01)$ in Meishan than in Whitecross boars $\left(15.7 \pm 2.1\right.$ versus $\left.29.3 \pm 2.7 \times 10^{6}\right)$. In addition, the total number of elongated spermatids per Sertoli cell $(14.12 \pm 1.5$ versus $7.5 \pm 0.7)$ was essentially doubled in Meishan versus Whitecross boars, respectively. Hence, in Meishan boars, prolonged exposure of the testes to increased FSH and testosterone concentrations, respectively, may result in Sertoli cells that function more efficiently.

While germ cell degeneration is considered a normal feature of spermatogenesis (Roosen-Runge and Giesel, 1950; Barr et al., 1971), it plays a critical role in quantitative aspects of spermatogenesis (Huckins, 1978; Johnson et al., 1983). In bulls (Amann, 1970; Berndston and Desjardins, 1974), mice (Oakberg, 1956), microwave-irradiated rats (Johnson et al., 1984a), and goats (Bilaspuri and Guraya, 1984), no degeneration of primary spermatocytes was reported until the first reduction division. However, during the first and second reduction divisions, we observed a spermatid yield which was $32.6 \%$ less than the theoretical yield when all the breeds were combined. This was sufficient to alter the population of the maturation phase spermatids and, ultimately, the daily sperm production in all the three breeds. In goats (Bilaspuri and Guraya, 1984) and buffalo (Bilaspuri and Guraya, 1980), similar germ cell losses of $10.4 \%$ and $9 \%$, respectively, have been reported, while bulls had a $20 \%$ degeneration during the reduction divisions (Attal and Courot, 1963). In humans, significant germ cell degeneration occurs in postprophase of meiosis with the percentage ranging from 10 to $95 \%$ in younger men (Johnson et al., 1983) and from 61 to $100 \%$ in older men (Johnson et al., 1990). No significant degeneration during spermiogenesis has been reported in previous studies involving bulls (Amann, 1962), stallions (Johnson, 1985), adult Sprague-Dawley rats (Johnson et al., 1984b) and humans (Johnson et al., 1981).

In the present study, a minimal germ cell loss of $8.6 \%$ was found during spermiogenesis. Thus, given no loss in potential sperm production during spermiogenesis in these breeds, coupled with the near absence of degeneration during the long meiotic prophase, germ cell degeneration during postprophase of meiosis $(32.6 \%)$ had a significant impact on daily sperm production. This impact is generalized among the three breeds, and, therefore, cannot explain the breed differences in daily sperm production. We postulate that variations in the size of the population of Sertoli cells and A spermatogonia coupled with a trend for increased germ cell degeneration during meiosis in the West African breed explain breed variations in the number of spermatozoa in the ejaculates from the three breeds.

The authors wish to thank V. Hardy, A. Kruger, D. Clopton, and L. Suggs for excellent technical assistance. M. Powell provided expert secretarial assistance. 
This work was supported by the World Bank and USDA ARS. Trade names are necessary to report factually on available data; however, the USDA neither guarantees nor warrants the standard of the product, and the use of the name by USDA implies no approval of the product to the exclusion of others that may also be suitable.

\section{References}

Akinkpelumi B (1981) Semen Characteristics of the West African Indigenous Boar MS Thesis, University of Nigeria, Nsukka

Almquist JO and Amann RP (1961) Reproductive capacity of dairy bulls. II. Gonadal and extra-gonadal sperm reserves as determined by direct counts and depletion trials, dimensions, and weight of genitalia Joumal of Dairy Science 44 1668-1678

Amann RP (1962) Reproductive capacity of dairy bulls. IV. Spermatogenesis and testicular germ cell degeneration American Journal of Anatomy 110 69-78

Amann RP (1970) Sperm production rates. In The Testis Vol. 1 pp 433-482 Eds AD Johnson, WR Gomes and NL VanDemark. Academic Press, New York

Amann RP (1981) A critical review of methods for evaluation of spermatogenesis from seminal characteristics Journal of Andrology 2 37-58

Amann RP and Lambiase JT, Jr (1969) The male rabbit. III. Determination of daily sperm production by means of testicular homogenates Journal of Animal Science 28 369-374

Amann RP, Kavanaugh JF, Griel LCJ and Voglmayr JK (1974) Sperm production of Holstein bulls determined from testicular spermatid reserves, after cannulation of rete testis or vas deferens, and by daily ejaculation Journal of Dairy Science 57 93-99

Amann RP, Johnson L, Thompson DL, Jr and Pickett BW (1976) Daily spermatozoal production, epididymal spermatozoal reserves and transit time of spermatozoa through the epididymis of the Rhesus monkey Biology of Reproduction 15 586-592

Attal J and Courot M (1963) Development testiculaire et éstablissement de la spermatogenése chez le taureau. Testicular development and onset of spermatogenesis in bulls Annales de Biologie Animale. Biochimie, Biophysigue 3 219-241

Barr AB, Moore DJ and Paulsen CA (1971) Germinal cell loss during human spermatogenesis Journal of Reproduction and Fertility 25 75-80

Berndtson WE (1977) Methods for quantifying mammalian spermatogenesis: a review Journal of Anima! Science 44 818-833

Berndtson WE and Desjardins C (1974) The cycle of the seminiferous epithelium and spermatogenesis in the bovine testis Amterican Journal of Anatomy 140 $167-180$

Berndtson WE and Igboeli G (1989) Numbers of Sertoli cells, quantitative rates of sperm production, and the efficiency of spermatogenesis in relation to the daily sperm output and seminal quality of young beef bulls American Journal of Veterinary Research 50 1193-1197

Berndtson WE and Thompson TL (1990) Changing relationships between testis size, Sertoli cell number and spermatogenesis in Sprague-Dawley rats Journal of Andrology 11 429-435

Berndtson WE, Igboeli G and Parker WG (1987) The numbers of Sertoli cells in mature Holstein bulls and their relationship to quantitative aspects of spermatogenesis Biology of Reproduction 37 60-67

Bilaspuri GS and Guraya SS (1980) Quantitative studies on spermatogenesis in buffalo (Bubalus bubalis) Reproduction, Nutrition, and Development 20 975-982

Bilaspuri GS and Guraya SS (1984) The seminiferous epithelial cycle and spermatogenesis in goats (Capra hircus) Journal of Agricultural Science Cambridge 103 359-368

Birkett JD \{1958\} Symposium on Animal Trypanosomiasis CCTA Publication No 45 , p. 32

Borg KE, Lunstra DD and Christenson RK (1993) Semen characteristics, testicular size, and reproductive hormone concentrations in mature Duroc, Meishan, Fengjing, and Minzhu boars Biology of Reproduction 49 515-521

Chalkley HW (1943) Method for the quantitative morphologic analysis of tissues Journal of the National Cancer Institute 4 47-53

Clermont $\mathrm{Y}$ and Trott $\mathbf{M}$ (1969) Duration of the cycle of the seminiferous epithelium in the mouse and hamster determined by means of ${ }^{3} \mathrm{H}$-thymidine and radioautography Fertility and Sterility 20 805-817
Curtis GM (1918) The morphology of the mammalian seminiferous tubule American Journal of Anatomy 24 339-394

Egbunike GN and Steinbach J (1976) Comparative studies on sperm production in boars raised in temperate and tropical climates Proceedings of the 8th International Congress on Animal Reproduction and Artificial Insemination (Krakow) 4 42-45

Egbunike GN, Holtz W, Endell W and Smidt D (1975) Reproductive capacity of German Landrace boars. I. Gonadal and extragonadal sperm reserves Zuchthygiene 10 184-187

Franca LR (1992) Daily sperm production in Piau boars estimated from Sertoli cell population and Sertoli cell index Proceedings of the 12th International Congress on Animal Reproduction and Artificial Insemination (The Hague) 4 $1716-1718$

Haley CS, Ashworth CJ, Lee GJ, Wilmut I, Aitken RP and Ritchie W (1990) British studies of the genetics of prolificacy in the Meishan pig. In Symposium sur le Porc Chinois pp 85-97 Eds M Molenat and C Legault. INRA, Paris

Harayama H, Nanjo I, Kanda S and Kato S (1991) Testicular development in Chinese Meishan boars Theriogenology 36 637-643

Hochereau-de Reviers MT (198I) Control of spermatogonial multiplication. In Reproductive Processes and Contraception pp 307-331 Ed. KW McKerns. Plenum Press, New York

Hochereau-de Reviers MT, Perreau C, Pisselet C, Fontaine I and Monet-Kuntz C (1990) Comparisons of endocrinological and testis parameters in 18-monthold Ile de France and Romanov rams Domestic Animal Endocrinology 7 63-73

Huckins C (1978) The morphology and kinetics of spermatogonial degeneration in normal adult rats: an analysis using a simplified classification of the germinal epithelium Anatomical Record 190 905-926

Humason GL (1967) Animal Tissue Techniques 2nd Edn p 16. WH Freeman, San Francisco

Johnson L (1985) Increased daily sperm production in the breeding season of stallions is explained by an elevated population of spermatogonia Biology of Reproduction 32 1181-1190

Johnson L (1986a) A new approach to quantification of Sertoli cells that avoids problems associated with the irregular nuclear surface Anatomical Record 214 $231-237$

Johnson L (1986b) Review article: spermatogenesis and aging in the human Journal of Andrology 7 331-354

Johnson L (1991a) Seasonal differences in equine spermatocytogenesis Biology of Reproduction 44 284-291

Johnson L (1991b) Spermatogenesis. In Reproduction in Domestic Animals (4th Edn) pp 173-219 Ed PT Cupps. Academic Press, New York

Johnson L and Neaves WB (1981) Age-related changes in the Leydig cell population, seminiferous tubules, and sperm production in stallions Biology of Reproduction 24 703-712

Johnson L and Thompson DL, Jr (1983) Age-related and seasonal variation in the Sertoli cell population, daily sperm production and serum concentrations of follicle-stimulating hormone, luteinizing hormone and testosterone in stallions Biology of Reproduction 29 777-789

Johnson L, Petty CS and Neaves WB (1980) A comparative study of daily sperm production and testicular composition in humans and rats Biology of Reproduction 22 1233-1243

Johnson L, Petty CS and Neaves WB (1981) A new approach to quantification of spermatogenesis and its application to germinal cell attrition during human spermiogenesis Biology of Reproduction 25 217-226

Johnson L, Petty CS and Neaves WB (1983) Further quantification of human spermatogenesis: germ cell loss during postprophase of meiosis and its relationship to daily sperm production Biology of Reproduction 29 207-215

Johnson L, Zane RS, Petty CS and Neaves WB (1984a) Quantification of the human Sertoli cell population: its distribution, relation to germ cell numbers, and age-related decline Biology of Reproduction 31 785-795

Johnson L, Lebovitz RM and Samson WK (1984b) Germ cell degeneration in normal and microwave-irradiated rats: potential sperm production rates at different developmental steps in spermatogenesis Anatomical Record 209 501-507

Johnson L, Grumbles JS, Bagheri A and Petty CS (1990) Increased germ cell degeneration during postprophase of meiosis is related to increased serum follicle-stimulating hormone concentrations and reduced daily sperm production in aged men Biology of Reproduction 42 281-287

Johnson L, Carter GK, Varner DD, Taylor TS, Blanchard TL and Rembert MS (1994) The relationship of daily sperm production with number of Sertoli cells and testicular size in adult horses: role of primitive spermatogonia Journal of Reproduction and Fertility 100 315-321 
Kennelly JJ (1960) Spermatogenesis in Boars. I. The Testicular Epididymal Spermatozoan Reserves. II. Estimated Potential Daily Production of Spermatozoa. MS Thesis, Cornell University, Ithaca, NY

Kennelly JJ and Foote RH (1964) Sampling boar testes to study spermatogenesis quantitatively and to predict sperm production Journal of Animal Science 23 160-167

Kluin PM, Kramer MF and de Rooij DG (1984) Proliferation of spermatogonia and Sertoli cells in maturing mice Anatomy and Embryology 169 73-78

Lunstra DD, Borg KE and Klindt J (1992) Characterization of pubertal development in the Meishan Chinese boar Journal of Animal Science 70 Supplement 1267

Oakberg EF (1956) A description of spermiogenesis in the mouse and its use in analysis of the cycle of the seminiferous epithelium and germ cell renewal American Journal of Anatomy 99 391-413

Orgebin-Crist MC (1968) Gonadal and epididymal sperm reserves in the rabbit: estimation of the daily sperm production Journal of Reproduction and Fertility 15 15-25

Ortavant R, Courot M and Hochereau-de Reviers MT (1977) Spermatogenesis in Domestic Animals. In Reproduction in Domestic Animals (3rd Edn) pp 203-227 Eds HH Cole and PT Cupps. Academic Press, New York

Roosen-Runge EC and Giesel LO (1950) Quantitative studies on spermatogenesis in the albino rat American Journal of Anatomy 87 1-30

Rowley MJ and Heller CG (1971) Quantitation of the cells of the seminiferous epithelium of the human testis employing the Sertoli cell as a constant Zeitschrift fur Zeuforschung und Mikroskopische Anatomie (Berlin) $115461-472$

Russell LD and Peterson RN (1984) Determination of the elongate spermatidSertoli cell ratio in various mammals Journal of Reproduction and Fertility $\mathbf{7 0}$ 635-641

SAS Institute (1985) Statistical Analysis System User's Guide. pp 113-709 SAS Institute, Inc., Cary, NC
Schinckel A, Johnson RK, Pumfrey RA and Zimmerman DR (1983) Testicular growth in boars of different genetic lines and its relationship to reproductive performance Journal of Animal Science 56 1065-1076

Schinckel AP, Johnson RK and Kittok RJ (1984) Relationships among measures of testicular development and endocrine function in boars Journal of Animal Science 58 1255-1261

Sokal RR and Rohlf FJ (Eds) (1969) Biometry pp 198-201. WH Freeman and Co., San Francisco

Swierstra EE (1968a) Cytology and duration of the cycle of the seminiferous epithelium of the boar; duration of spermatozoan transit through the epididymis Anatomical Record 161 171-186

Swierstra EE (1968b) A comparison of spermatozoa production and spermatozoa output of Yorkshire and Lacombe boars Journal of Reproduction and Fertility 17 459-469

Swierstra EE (1970) The effect of low ambient temperatures on sperm production, epididymal sperm reserves, and semen characteristics of boars Biology of Reproduction 2 23-28

Swierstra EE (1973) Influence of breed, age, and ejaculation frequency on boar semen composition Canadian Journal of Animal Science 53 43-53

Verma MC, Singh G and Sharma UD (1965) Studies on sperm production II. Testicular and epididymal sperm reserves in buffalo-bulls as determined by direct counts Indian Journal of Veterinary Science and Animal Husbandry 35 331-337

Weibel ER and Paumgartner D (1978) Integrated stereological and biochemical studies on hepatocytic membranes. II. Correction of section thickness effect on volume and surface density estimates Journal of Cell Biology 77 584-597

Wise T, Lunstra DD and Ford JJ (1995) Differential pituitary and gonadal function of Chinese Meishan and European white composite boars: effects of $\mathrm{GnRH}$ stimulation, castration, and steroidal feedback Biology of Reproduction 54 I46-153 